\title{
Healthy changes in some cardiometabolic risk factors accompany the higher summertime serum 25-hydroxyvitamin D concentrations in Iranian children: National Food and Nutrition Surveillance
}

\author{
Bahareh Nikooyeh ${ }^{1}$, Zahra Abdollahi ${ }^{2}$, Majid Hajifaraji ${ }^{3}$, Hamid Alavi-Majd², \\ Forouzan Salehi ${ }^{4}$, Amir Hossein Yarparvar ${ }^{5}$ and Tirang R Neyestani ${ }^{1, *}$ \\ 'Laboratory of Nutrition Research, National Nutrition and Food Technology Research Institute, Faculty of Nutrition \\ Sciences and Food Technology, Shahid Beheshti University of Medical Sciences, PO Box 19395-4741, Tehran, \\ Islamic Republic of Iran: ${ }^{2}$ Department of Biostatistics, Shahid Beheshti University of Medical Sciences, Tehran, Islamic \\ Republic of Iran: ${ }^{3}$ Department of Nutritional Policy-Making Research, National Nutrition and Food Technology \\ Research Institute and Faculty of Nutrition Sciences and Food Technology, Shahid Beheshti University of Medical \\ Sciences, Tehran, Islamic Republic of Iran: ${ }^{4}$ Nutrition Office, Iran Ministry of Health, Treatment and Medical \\ Education, Tehran, Islamic Republic of Iran: ${ }^{5}$ UNICEF Office, Tehran, Islamic Republic of Iran
}

Submitted 7 July 2017: Final revision received 29 January 2018: Accepted 16 February 2018: First published online 27 March 2018

\begin{abstract}
Objective: To investigate seasonal variations of vitamin D status at different latitudes and if these changes are accompanied by corresponding variations in certain health parameters in children living in a broad latitudinal range in Iran. Design: Longitudinal study.

Subjects: In total, 530 apparently healthy children aged 5-18 years were randomly selected from six regions of Iran with a latitudinal gradient from $29^{\circ} \mathrm{N}$ to $37 \cdot 5^{\circ} \mathrm{N}$. All anthropometric and biochemical assessments were performed twice during a year (summer, winter). High BMI ( $Z$-score $>1)$, low HDL cholesterol $(<40 \mathrm{mg} / \mathrm{dl}$, males; $<50 \mathrm{mg} / \mathrm{dl}$, females) and high TAG $(>150 \mathrm{mg} / \mathrm{dl})$ were considered cardiometabolic risk factors.

Results: Serum 25-hydroxyvitamin D (25(OH)D) showed between-season variation, with significantly higher concentrations (mean (SD)) in summer $v$. winter ( 43 (29) v. 27 (18) nmol/1; $P<0 \cdot 001)$. Change of circulating 25(OH)D between summer and winter was negatively correlated with change of BMI $(r=-0 \cdot 16$; $P<0.001)$, TAG $(r=-0.09 ; P=0.04)$ and total cholesterol $(r=-0.10 ; P=0.02)$ and directly correlated with change of height-for-age $Z$-score $(r=0.09 ; P=0.04)$. Multiple stepwise linear regression analysis $(\beta ; 95 \% \mathrm{CI})$ showed that winter serum 25(OH)D $(-0.3 ;-0 \cdot 4,-0 \cdot 2 ; P<0 \cdot 001)$, gender (boys $v$ girls: $9 \cdot 7 ; 5 \cdot 2,14 \cdot 1$; $P<0 \cdot 001)$ and latitude $\left(>33^{\circ} \mathrm{N} v .<33^{\circ} \mathrm{N}: 4 \cdot 5 ; 0 \cdot 09,9 \cdot 0 ; P=0 \cdot 04\right)$ were predictors of change of serum $25(\mathrm{OH}) \mathrm{D}$ between two seasons.

Conclusions: Summertime improvement of vitamin D status was accompanied by certain improved cardiometabolic risk factors, notably serum TAG, total cholesterol and BMI, in children.
\end{abstract}

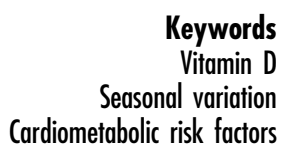

Keywords

Vitamin D Cardiometabolic risk factors
Previous studies have shown a seasonal variation in vitamin $\mathrm{D}$ status as reflected by higher blood concentrations of 25-hydroxyvitamin D (25(OH)D) in summertime than in wintertime ${ }^{(1,2)}$. At high northern latitudes, season greatly influences circulating $25(\mathrm{OH}) \mathrm{D}$ concentrations. Indeed, dermal generation of vitamin $\mathrm{D}$ declines dramatically from October to March so that even a long time spent doing outdoor activities cannot provide enough endogenous vitamin D for the body ${ }^{(3)}$. Moreover, even living in sunny regions cannot guarantee sufficient dermal vitamin D synthesis because of such lifestyle factors as reduced outdoor activities and sunscreen use ${ }^{(4)}$. On the other hand, the scarcity of natural dietary sources of vitamin $\mathrm{D}$ in amounts needed to reach adequate concentrations of circulating $25(\mathrm{OH}) \mathrm{D}$ is a major contributor to the vitamin D deficiency epidemic ${ }^{(5,6)}$.

The main source of vitamin $\mathrm{D}$ in most populations is photo-conversion of the precursor 7-dehydrocholesterol to previtamin D upon skin exposure to solar UV radiation (UVB; wavelength $=290-315 \mathrm{~nm}$ ). Several modifiable as well as non-modifiable factors can influence vitamin D status including age, latitude, skin pigmentation, body fat 
and season ${ }^{(7,8)}$. Poor vitamin D status, even in its subclinical form, is now recognized as one of the contributing factors in a wide range of human diseases including cancers, autoimmune diseases, diabetes, infectious diseases and cardiovascular disorders ${ }^{(9-11)}$. Several population-based studies have reported the high prevalence of hypovitaminosis D among all age groups worldwide ${ }^{(12-14)}$.

A growing body of evidence indicates an association between poor vitamin $\mathrm{D}$ status and increased risk of $\mathrm{CVD}^{(15-17)}$. A meta-analysis of cross-sectional and observational studies demonstrated a $43 \%$ reduction in CVD occurrence in individuals with sufficient circulating $25(\mathrm{OH}) \mathrm{D}$ concentrations ${ }^{(16)}$.

There are several ways through which vitamin D deficiency could potentially influence CVD, including increased insulin resistance, hypertension, increased pro-inflammatory cytokine formation, obesity and dyslipidaemia ${ }^{(18,19)}$. Several studies have reported an association of serum 25(OH)D with body fat and certain metabolic indicators ${ }^{(20,21)}$.

Alarming high prevalence of poor vitamin D status among Iranians in almost all age and sex groups ${ }^{(12,22-26)}$ convinced stakeholders at the Iranian Ministry of Health to take immediate action. As the first step, monthly vitamin D supplementation was started in 2014 for schoolchildren, first in girls' schools in thirteen provinces. This was then extended to boys' schools and other provinces. Obviously, many other subpopulations than schoolchildren were out of the coverage of this programme. Later, policy makers at the Ministry of Health decided to implement a national fortification programme to alleviate vitamin D deficiency in the many subpopulations not covered by the schoolchildren's supplementation programme. A national vitamin D fortification programme would provide a sustainable approach with a wider coverage of individuals at risk of vitamin D deficiency. Before implementation of a national vitamin $\mathrm{D}$ fortification programme, it is necessary to first determine how the country's wide range of latitudes (29 to $37^{\circ} \mathrm{N}$ ), climatic and seasonal changes impact circulating $25(\mathrm{OH}) \mathrm{D}$ in Iranian adults and children $^{(27)}$. Prior to launching a national fortification programme, it is also critical to determine the possible effects of vitamin D status on different health aspects of the population which may vary with latitude, climate and season $^{(27)}$. The goal of the present paper is to provide important information on the seasonal variation of vitamin D status in different regions of Iran and to determine if these changes are accompanied by corresponding variations in anthropometric as well as blood lipid components of children. To do this, a longitudinal study on a sample of apparently healthy children across a broad latitudinal range in Iran was conducted.

\section{Participants and methods}

The participants were part of the study population of the National Food and Nutrition Surveillance Program
(NFNSP), a population-based study to examine and monitor the nutritional status of the Iranian population.

In total, $530(51.5 \%$ girls, $48.5 \%$ boys $)$ apparently healthy children aged 5-18 years were randomly selected from the registered population, and stratified for age and gender, from six regions of Iran with a latitudinal gradient from $29^{\circ} \mathrm{N}$ to $37.5^{\circ} \mathrm{N}$. They included (latitude, longitude): West Azarbaijan (province 1: $37.5^{\circ} \mathrm{N}, 45 \cdot 0^{\circ} \mathrm{E}$ ), Semnan (province $2: 35 \cdot 5^{\circ} \mathrm{N}, 53.3^{\circ} \mathrm{E}$ ), Lorestan (province $3: 33.4^{\circ} \mathrm{N}$, $48 \cdot 3^{\circ} \mathrm{E}$ ), South Khorasan (province $4: 32 \cdot 8^{\circ} \mathrm{N}, 59 \cdot 2^{\circ} \mathrm{E}$ ), Khoozestan (province 5: $31.3^{\circ} \mathrm{N}, 48.6^{\circ} \mathrm{E}$ ) and Fars (province 6: $29 \cdot 6^{\circ} \mathrm{N}, 52 \cdot 5^{\circ} \mathrm{E}$ ).

None of the children had a history of hepatic or renal disorders and none were taking vitamin D supplements or medications affecting vitamin D metabolism such as anticonvulsants or corticosteroids. All children provided written informed consents and all questionnaires and procedures were approved by the Ethical Committee of the National Nutrition and Food Technology Research Institute (NNFTRI). All children were visited twice during a year, summer (August-September) and winter (February-March).

\section{Questionnaires}

Demographic data were obtained by face-to-face interview and completing the questionnaires. Two different measures were used to express the usual sun exposure habits: (i) the duration of direct sun exposure during typical days, dichotomized as $<1 \mathrm{~h} / \mathrm{d}$ and $>1 \mathrm{~h} / \mathrm{d}$; and (ii) the time of day of sun exposure, dichotomized as 10.0015.00 hours (the peak time of solar UV radiation reaching the Earth) and other times of day ${ }^{(28)}$.

\section{Antbropometrics}

Height was measured using a wall-mounted stadiometer accurate to the nearest $0 \cdot 1 \mathrm{~cm}$, and weight was measured while participants were wearing light clothing and no shoes with a digital scale accurate to the nearest $0.1 \mathrm{~kg}$. Both instruments were calibrated daily. BMI was defined as [weight $(\mathrm{kg})] /[\text { height }(\mathrm{m})]^{2}$. Overweight and obesity were categorized using BMI-for-age $Z$-score (BMIZ): overweight, $\mathrm{BMIZ}=+1$ to +2 ; obesity, $\mathrm{BMIZ}>+2$.

\section{Laboratory investigations}

Blood samples, drawn in the morning (08.00-10.00 hours) after an overnight fast, were centrifuged at room temperature for $10 \mathrm{~min}$ at $800 \boldsymbol{g}$ to separate sera, which were then aliquoted and stored immediately at $-80^{\circ} \mathrm{C}$ until the day of analysis.

Total cholesterol, TAG, LDL cholesterol and HDL cholesterol concentrations were measured using enzymatic methods (Pars-Azmoon, Tehran, Iran) and an auto-analyser (Selecta E; Vitalab, Holliston, the Netherlands). High BMI (BMIZ $>+1)$, low HDL cholesterol $(<40 \mathrm{mg} / \mathrm{dl}$ in males and $<50 \mathrm{mg} / \mathrm{dl}$ in females $)$ and high TAG $(>150 \mathrm{mg} / \mathrm{dl})$ were considered cardiometabolic risk factors. 
Serum concentrations of $25(\mathrm{OH}) \mathrm{D}$ were determined by a direct ELISA method (DIAsource ImmunoAssays, Louvain-la-Neuve, Belgium). According to the manufacturer, the intra- and inter-assay $\mathrm{CV}$ were $2 \cdot 5-7 \cdot 8 \%$ (for values $13 \cdot 7-203 \mathrm{nmol} / \mathrm{l}$ ) and $4.3-9 \cdot 2 \%$ (for values $44 \cdot 25-213 \cdot 7 \mathrm{nmol} / \mathrm{l})$, respectively. Considering the importance of comparability of $25(\mathrm{OH}) \mathrm{D}$ assay results in future studies $^{(29)}$, the accuracy of $25(\mathrm{OH}) \mathrm{D}$ concentration measurements was ensured using HPLC ${ }^{(30)}$ in the Laboratory of Nutrition Research, NNFTRI, that has been participating in the Vitamin D External Quality Assessment Scheme (DEQAS) since 2012. Calibrated systems and control sera were also employed as the main steps of standardization of the $25(\mathrm{OH}) \mathrm{D}$ assay ${ }^{(31)}$.

Vitamin D status was defined based on serum concentrations of $25(\mathrm{OH}) \mathrm{D}$ as follows: vitamin D deficiency, $25(\mathrm{OH}) \mathrm{D}<25 \mathrm{nmol} / \mathrm{l}$; vitamin D insufficiency, 25(OH)D $=25$ $50 \mathrm{nmol} / \mathrm{l}$; and optimal status, $25(\mathrm{OH}) \mathrm{D}>50 \mathrm{nmol} / \mathrm{l}^{(11,32)}$.

\section{Statistical analyses}

Continuous variables were expressed as mean and SD; categorical variables as frequencies and percentages. Normality of distribution was checked for all variables using the Kolmogorov-Smirnov test. Tests for differences in continuous variables among latitudes were performed using ANOVA or the Kruskal-Wallis test. Significant differences for categorical variables were determined by the $\chi^{2}$ test. Comparisons of change of variables between summer and winter were made by the paired $t$ test or Wilcoxon's test, as appropriate. A two-way ANOVA was conducted to examine the effect of latitude $\left(>33^{\circ} \mathrm{N} v .<33^{\circ}\right.$ $\mathrm{N}$ ) and gender (boys $v$. girls) on change in $25(\mathrm{OH}) \mathrm{D}$ between summer and winter. Two-way multivariate ANOVA was used to assess the effect of latitude and gender on the combined change in BMI and lipid profile variables. Pearson's correlation coefficient and multiple linear and logistic regression analysis were used to assess relationships between variables. A two-tailed $P<0.05$ was considered significant. Analyses were conducted using the statistical software package IBM SPSS Statistics for Windows, version 21.0.

\section{Results}

\section{Study population}

General characteristics of the study population are presented in Table 1. At the beginning of the study, the mean of age of children was 11 (SD 4) years. No age difference was found between boys and girls (11 (SD 4) v. 11 (sD 4) years; $P=0 \cdot 24$ ).

\section{Vitamin D status}

Mean serum 25(OH)D showed a between-season variation, with significantly higher concentration in summer than in winter (43.2 (SD 29.2) v. 27.4 (sD 18.0) nmol/l; $P<0.001)$. Both serum concentration in winter and the summer rise of $25(\mathrm{OH}) \mathrm{D}$ were higher in boys than in girls (winter: 31.0 (sD 16.1) v. $24 \cdot 2$ (sD 18.2) nmol/1; $P<0.001$; summer rise: $+19 \cdot 0(\mathrm{SD} 25 \cdot 0) v .+11.5(\mathrm{SD} 20 \cdot 4) \mathrm{nmol} / \mathrm{l}$; $P<0 \cdot 001$; Table 1).

Vitamin D status in latitudes below and above $33^{\circ} \mathrm{N}$ is shown in Table 2. Two-way ANOVA was performed to examine the effect of latitude $\left(>33^{\circ} \mathrm{N} v \cdot<33^{\circ} \mathrm{N}\right)$ and gender (boys $v$. girls) on change in $25(\mathrm{OH}) \mathrm{D}$ between summer and winter. It was shown that change in $25(\mathrm{OH}) \mathrm{D}$ concentration was significantly associated with both latitude (19.0 (SD 19.0) $\mathrm{nmol} / 1$ in $<33^{\circ} \mathrm{N} v \cdot 13 \cdot 1$ (sD $\left.31 \cdot 0\right) \mathrm{nmol} / \mathrm{l}$ in $>33^{\circ} \mathrm{N}$; $P=0.02$ ) and gender (19.3 (SD 28.0) nmol/1 in boys $v .12 \cdot 0$ (sD 25.0$) \mathrm{nmol} / 1$ in girls; $P<0.001$ ). No significant interaction between latitude and gender was found $(P=0 \cdot 06)$.

Table 1 Comparison of serum 25-hydroxyvitamin $\mathrm{D}(25(\mathrm{OH}) \mathrm{D})$, lipid profile and duration of sun exposure between summer and winter in boys, girls and the total sample: 530 apparently healthy children aged 5-18 years from six Iranian provinces with a latitudinal gradient from $29^{\circ} \mathrm{N}$ to $37.5^{\circ} \mathrm{N}$ (summer, August-September; winter, February-March)

\begin{tabular}{|c|c|c|c|c|c|c|c|c|c|c|c|c|c|c|c|}
\hline \multirow[b]{3}{*}{ Variable } & \multicolumn{4}{|c|}{ Boys } & \multirow[b]{3}{*}{$P$ value } & \multicolumn{4}{|c|}{ Girls } & \multirow[b]{3}{*}{$P$ value } & \multicolumn{4}{|c|}{ Total sample } & \multirow[b]{3}{*}{$P$ value } \\
\hline & \multicolumn{2}{|c|}{ Winter } & \multicolumn{2}{|c|}{ Summer } & & \multicolumn{2}{|c|}{ Winter } & \multicolumn{2}{|c|}{ Summer } & & \multicolumn{2}{|c|}{ Winter } & \multicolumn{2}{|c|}{ Summer } & \\
\hline & Mean & SD & Mean & SD & & Mean & SD & Mean & SD & & Mean & SD & Mean & SD & \\
\hline $25(\mathrm{OH}) \mathrm{D}(\mathrm{nmol} / \mathrm{l})$ & 31.0 & $16 \cdot 1$ & $50 \cdot 0$ & $30 \cdot 0$ & $<0.001$ & 24.2 & $18 \cdot 2$ & $36 \cdot 0$ & $26 \cdot 1$ & $<0.001$ & 27.4 & $18 \cdot 0$ & 43.2 & 29.2 & $<0.001$ \\
\hline TAG (mg/dl) & 87 & 49 & 86 & 44 & 0.77 & 80 & 36 & 83 & 31 & 0.08 & 83 & 43 & 85 & 38 & 0.22 \\
\hline $\mathrm{TC}(\mathrm{mg} / \mathrm{dl})$ & 140 & 28 & 140 & 31 & 0.71 & 141 & 25 & 143 & 29 & 0.11 & 140 & 27 & 141 & 30 & 0.37 \\
\hline LDL-C (mg/dl) & 72 & 23 & 70 & 26 & 0.25 & 74 & 21 & 75 & 24 & 0.34 & 73 & 22 & 73 & 25 & 0.83 \\
\hline $\mathrm{HDL}-\mathrm{C}(\mathrm{mg} / \mathrm{dl})$ & 51 & 12 & 53 & 12 & 0.03 & 51 & 10 & 53 & 11 & $<0.001$ & 51 & 11 & 53 & 11 & $<0.001$ \\
\hline \multicolumn{16}{|l|}{ Sun exposure (\%) } \\
\hline$<1 \mathrm{~h} / \mathrm{d}$ & \multirow{2}{*}{\multicolumn{2}{|c|}{$\begin{array}{l}54 \cdot 7 \\
45 \cdot 3\end{array}$}} & \multirow{2}{*}{\multicolumn{2}{|c|}{$\begin{array}{l}37 \cdot 1 \\
62 \cdot 8\end{array}$}} & $<0.001$ & \multirow{2}{*}{\multicolumn{2}{|c|}{$\begin{array}{l}72 \cdot 6 \\
27 \cdot 4\end{array}$}} & \multirow{2}{*}{\multicolumn{2}{|c|}{$\begin{array}{l}69.6 \\
30.4\end{array}$}} & 0.54 & \multirow{2}{*}{\multicolumn{2}{|c|}{$\begin{array}{l}63 \cdot 8 \\
36 \cdot 2\end{array}$}} & \multirow{2}{*}{\multicolumn{2}{|c|}{$\begin{array}{l}53 \cdot 8 \\
46 \cdot 2\end{array}$}} & 0.001 \\
\hline$>1 \mathrm{~h} / \mathrm{d}$ & & & & & & & & & & & & & & & \\
\hline \multicolumn{16}{|c|}{ Time of day of sun exposure (\%) } \\
\hline $10.00-15.00$ hours & \multirow{2}{*}{\multicolumn{2}{|c|}{$\begin{array}{l}56.0 \\
44.0\end{array}$}} & \multirow{2}{*}{\multicolumn{2}{|c|}{$\begin{array}{l}74.9 \\
25 \cdot 1\end{array}$}} & $<0.001$ & \multirow{2}{*}{\multicolumn{2}{|c|}{$\begin{array}{l}43.3 \\
56 \cdot 7\end{array}$}} & \multirow{2}{*}{\multicolumn{2}{|c|}{$\begin{array}{l}59 \cdot 6 \\
40 \cdot 4\end{array}$}} & $<0.001$ & \multirow{2}{*}{\multicolumn{2}{|c|}{$\begin{array}{l}49 \cdot 4 \\
50 \cdot 6\end{array}$}} & \multirow{2}{*}{\multicolumn{2}{|c|}{$\begin{array}{l}67.0 \\
33.0\end{array}$}} & $<0.001$ \\
\hline Other & & & & & & & & & & & & & & & \\
\hline \multicolumn{16}{|l|}{ Sunscreen use (\%) } \\
\hline No & \multirow{2}{*}{\multicolumn{2}{|c|}{$\begin{array}{c}98.1 \\
1.9\end{array}$}} & \multirow{2}{*}{\multicolumn{2}{|c|}{$\begin{array}{c}97.7 \\
2.3\end{array}$}} & 1.00 & \multirow{2}{*}{\multicolumn{2}{|c|}{$\begin{array}{c}91.5 \\
8.5\end{array}$}} & \multirow{2}{*}{\multicolumn{2}{|c|}{$\begin{array}{c}90.7 \\
9.3\end{array}$}} & 0.5 & \multirow{2}{*}{\multicolumn{2}{|c|}{$\begin{array}{c}94.7 \\
5.3\end{array}$}} & 94 & & 0.25 \\
\hline Yes & & & & & & & & & & & & & 5 & & \\
\hline
\end{tabular}

TC, total cholesterol; LDL-C, LDL cholesterol; HDL-C, HDL cholesterol. 
Table 2 Comparison of vitamin D status by latitude and season, and by season among the total sample: 530 apparently healthy children aged 5-18 years from six Iranian provinces with a latitudinal gradient from $29^{\circ} \mathrm{N}$ to $37.5^{\circ} \mathrm{N}$ (summer, August-September; winter, February-March)

\begin{tabular}{|c|c|c|c|c|c|c|c|c|c|c|c|c|c|c|c|}
\hline \multirow[b]{4}{*}{ Vitamin D status ${ }^{*}$} & \multicolumn{10}{|c|}{ Latitude } & & & & & \\
\hline & \multicolumn{4}{|c|}{$<33^{\circ} \mathrm{N}$} & \multirow[b]{3}{*}{$P$ value } & \multicolumn{5}{|c|}{$>33^{\circ} \mathrm{N}$} & \multicolumn{5}{|c|}{ Total } \\
\hline & \multicolumn{2}{|c|}{ Summer } & \multicolumn{2}{|c|}{ Winter } & & \multicolumn{2}{|c|}{ Summer } & \multicolumn{2}{|c|}{ Winter } & \multirow[b]{2}{*}{$P$ value } & \multicolumn{2}{|c|}{ Summer } & \multicolumn{2}{|c|}{ Winter } & \multirow[b]{2}{*}{$P$ value } \\
\hline & $n$ & $\%$ & $n$ & $\%$ & & $n$ & $\%$ & $n$ & $\%$ & & $n$ & $\%$ & $n$ & $\%$ & \\
\hline Deficiency & 99 & $31 \cdot 1$ & 189 & $60 \cdot 0$ & $<0.001$ & 36 & $16 \cdot 8$ & 112 & $52 \cdot 1$ & $<0.001$ & 135 & 25.5 & 301 & $56 \cdot 8$ & $<0.001$ \\
\hline Insufficiency & 143 & $45 \cdot 3$ & 98 & $31 \cdot 1$ & & 102 & $47 \cdot 7$ & 95 & $44 \cdot 2$ & & 245 & $46 \cdot 2$ & 193 & $36 \cdot 4$ & \\
\hline Sufficiency & 74 & 23.4 & 28 & 8.9 & & 76 & $35 \cdot 5$ & 8 & $3 \cdot 7$ & & 150 & $28 \cdot 3$ & 36 & $6 \cdot 8$ & \\
\hline
\end{tabular}

*Vitamin D status was defined based on serum 25-hydroxyvitamin $\mathrm{D}(25(\mathrm{OH}) \mathrm{D})$ concentration as: deficiency, 25(OH)D $\leq 25 \mathrm{nmol} / \mathrm{l}$; insufficiency, $25(\mathrm{OH}) \mathrm{D}=25-$ $50 \mathrm{nmol} / \mathrm{l}$; sufficiency, $25(\mathrm{OH}) \mathrm{D}>50 \mathrm{nmol} / \mathrm{l}$.

During winter and summer, $36 \cdot 2$ and $46 \cdot 2 \%$ of the children reported outdoor sun exposure for $>1 \mathrm{~h} / \mathrm{d}$, respectively. The children who had outdoor sun exposure for $>1 \mathrm{~h} / \mathrm{d}$ in summer, as compared with those with less solar exposure, had higher serum 25(OH)D concentration (48.0 (sD 30.0) v. 38.1（SD 27.1) nmol/l; $P<0.001)$.

A very high percentage of the children had circulating $25(\mathrm{OH}) \mathrm{D}$ concentration below $50 \mathrm{nmol} / \mathrm{l}$ during winter (93.4\%); this decreased in summer (71.7\%), although the prevalence of hypovitaminosis $\mathrm{D}$ was still remarkable. Vitamin D deficiency $(25(\mathrm{OH}) \mathrm{D}<25 \mathrm{nmol} / \mathrm{l})$ was detected in $71.2 \%$ of girls and $41.7 \%$ of boys in winter and $39.1 \%$ of girls and $11.2 \%$ of boys in summer (Fig. 1). In fact, $24.3 \%$ of children who had suboptimal vitamin D status in the winter were in the sufficient vitamin D category in summer.

\section{Anthropometry and lipid profile}

About 2.4 and $3.9 \%$ of children had height-for-age $Z$-score (HAZ) $<-2$ in summer and winter, respectively (Table 3 ). There was a significant increase in HAZ in summer, as compared with winter (0.6 (SD 1.2) v. $0 \cdot 22$ (SD 1.2); $P<0.001)$. The change in circulating $25(\mathrm{OH}) \mathrm{D}$ concentration between summer and winter was negatively correlated with the change in BMI $(r=-0 \cdot 16 ; P<0 \cdot 001)$, TAG $(r=-0.09 ; P=0.04)$ and total cholesterol $(r=-0 \cdot 10$; $P=0.02)$ and directly correlated with the change in HAZ $(r=0.09 ; P=0 \cdot 04)$.

According to BMIZ, 20.5 and $20.2 \%$ of the children were overweight/obese in winter and summer, respectively (Table 3). In summer, the overweight/obese children had 2.5 times higher risk of having undesirable vitamin D status (serum 25(OH)D $<50 \mathrm{nmol} / \mathrm{l}$ ) than the normalweight children $(\mathrm{OR}=2 \cdot 54 ; P=0 \cdot 001)$.

Among blood lipid profile components, only HDL cholesterol showed a seasonal variation $(P<0 \cdot 001)$ with no gender difference (Table 1 ). However, only in summer was circulating $25(\mathrm{OH}) \mathrm{D}$ inversely correlated with serum total cholesterol $(r=-0 \cdot 18 ; P<0 \cdot 001)$ and LDL cholesterol $(r=-0.12 ; \quad P=0 \cdot 01)$. The prevalence of undesirable
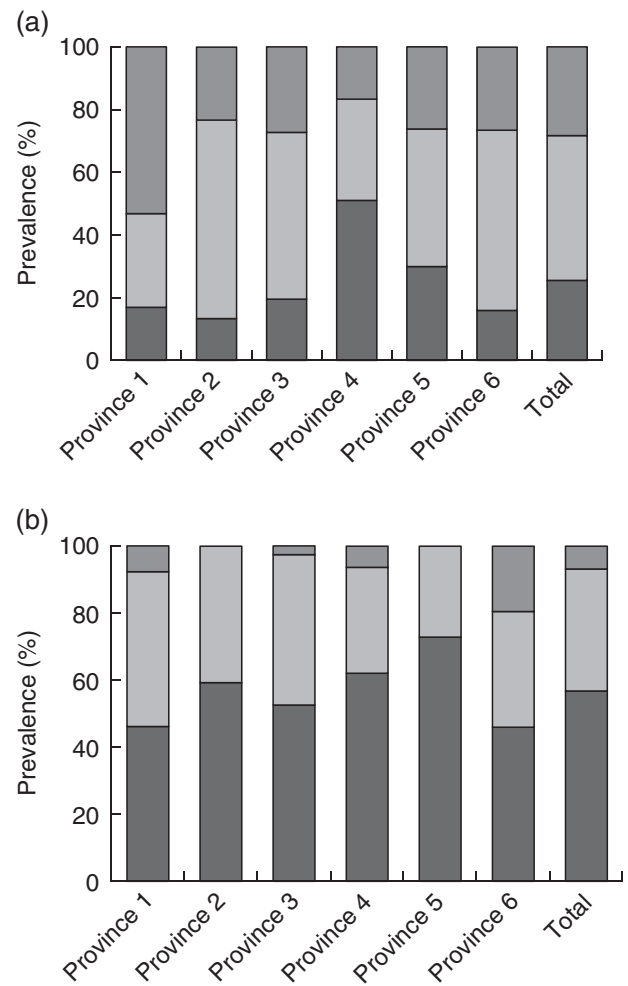

Fig. 1 Prevalence of vitamin D deficiency $(\square ; 25$-hydroxyvitamin D $(25(\mathrm{OH}) \mathrm{D}) \leq 25 \mathrm{nmol} / \mathrm{l})$, insufficiency $(\square ; 25(\mathrm{OH}) \mathrm{D}=25-$ $50 \mathrm{nmol} / \mathrm{l})$ and sufficiency $(\square ; 25(\mathrm{OH}) \mathrm{D}>50 \mathrm{nmol} / \mathrm{l})$ in 530 apparently healthy children aged $5-18$ years from six Iranian provinces with a latitudinal gradient from $29^{\circ} \mathrm{N}$ to $37.5^{\circ} \mathrm{N}$ : (a) summer (August-September) and (b) winter (February-March)

serum HDL cholesterol concentration was 27.4 and $31.7 \%$ in summer and winter, respectively.

The results showed that 43.8 and $36.7 \%$ of children had at least one of the predefined cardiometabolic risk factors in winter and summer, respectively, and this prevalence was significantly higher in winter compared with summer $(P<0.001)$. Moreover, about $10 \%$ of children had a combination of two cardiometabolic risk factors. Figure 2 summarizes the change in undesirable vitamin D status and cardiometabolic risk factors between the two seasons among the studied children. 
Table 3 Comparison of the occurrence of stunting, underweight, overweight and obesity between summer and winter in boys, girls and the total sample: 530 apparently healthy children aged 5-18 years from six Iranian provinces with a latitudinal gradient from $29^{\circ} \mathrm{N}$ to $37.5^{\circ} \mathrm{N}$ (summer, August-September; winter, February-March)

\begin{tabular}{|c|c|c|c|c|c|c|c|c|c|c|c|c|c|c|c|}
\hline & \multicolumn{5}{|c|}{ Boys } & \multicolumn{5}{|c|}{ Girls } & \multicolumn{5}{|c|}{ Total sample } \\
\hline & \multicolumn{2}{|c|}{ Winter } & \multicolumn{2}{|c|}{ Summer } & \multirow[b]{2}{*}{$P$ value } & \multicolumn{2}{|c|}{ Winter } & \multicolumn{2}{|c|}{ Summer } & \multirow[b]{2}{*}{$P$ value } & \multicolumn{2}{|c|}{ Winter } & \multicolumn{2}{|c|}{ Summer } & \multirow[b]{2}{*}{$P$ value } \\
\hline & $n$ & $\%$ & $n$ & $\%$ & & $n$ & $\%$ & $n$ & $\%$ & & $n$ & $\%$ & $n$ & $\%$ & \\
\hline \multicolumn{16}{|l|}{ HAZ (\%) } \\
\hline$<-2$ & 10 & 3.9 & 8 & $3 \cdot 1$ & 0.69 & 11 & 4.0 & 5 & $1 \cdot 8$ & 0.03 & 21 & 3.9 & 13 & $2 \cdot 4$ & 0.04 \\
\hline$>-2$ & 249 & $96 \cdot 1$ & 251 & $96 \cdot 9$ & & 249 & $96 \cdot 0$ & 270 & $98 \cdot 2$ & & 513 & $96 \cdot 1$ & 521 & $97 \cdot 6$ & \\
\hline \multicolumn{16}{|l|}{ BMIZ (\%) } \\
\hline Underweight, $<-2$ & 20 & 7.9 & 20 & $7 \cdot 9$ & 0.22 & 16 & $5 \cdot 9$ & 14 & $5 \cdot 3$ & 0.77 & 36 & 6.9 & 34 & $6 \cdot 6$ & 0.46 \\
\hline Normal, -2 to +1 & 174 & $68 \cdot 8$ & 179 & 70.5 & & 205 & $76 \cdot 2$ & 199 & $76 \cdot 0$ & & 379 & $72 \cdot 6$ & 378 & $73 \cdot 3$ & \\
\hline Overweight, +1 to +2 & 45 & $17 \cdot 8$ & 46 & $18 \cdot 1$ & & 41 & $15 \cdot 2$ & 42 & $16 \cdot 0$ & & 86 & $16 \cdot 5$ & 88 & $17 \cdot 1$ & \\
\hline Obese, $>+2$ & 14 & $5 \cdot 5$ & 9 & 3.5 & & 7 & $2 \cdot 6$ & 7 & $2 \cdot 7$ & & 21 & 4.0 & 16 & $3 \cdot 1$ & \\
\hline
\end{tabular}

HAZ, height-for-age Z-score; BMIZ, BMI-for-age Z-score.

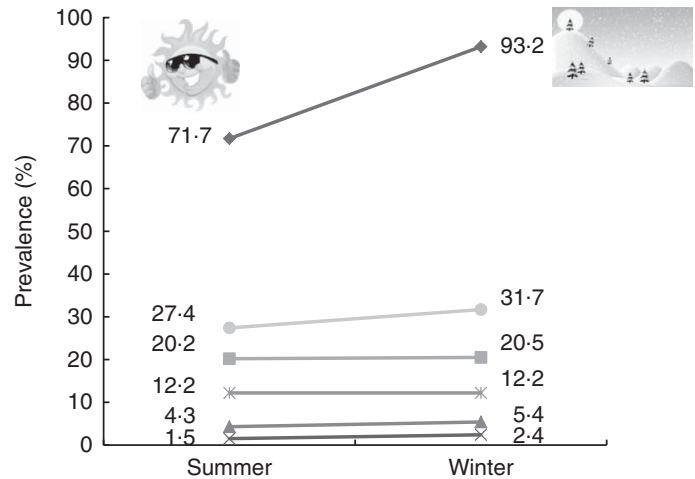

Fig. 2 The annual trend of change in undesirable vitamin $D$ status and cardiometabolic risk factors $(-\ldots$, poor vitamin $\mathrm{D}$ status; $-\longrightarrow$, high $\mathrm{BMI} ;-$, high TAG; $\longleftarrow$, high total cholesterol; —- high LDL cholesterol; —-, low HDL cholesterol) among 530 apparently healthy children aged 518 years from six Iranian provinces with a latitudinal gradient from $29^{\circ} \mathrm{N}$ to $37.5^{\circ} \mathrm{N}$ (summer, August-September; winter, February-March)

\section{Predictors of 25-bydroxyvitamin $D$ concentration}

In linear regression, the duration of sun exposure after adjusting for gender was found to be a significant predictor of serum $25(\mathrm{OH}) \mathrm{D}$ concentration in summer $(\beta=5 \cdot 2 ; 95 \%$ CI $0.2,10 \cdot 2 ; P=0.04)$. The preference for sun exposure when outside led to an increase of about $21 \%$ in circulating $25(\mathrm{OH}) \mathrm{D}$ in summer. However, after stratification by latitude $\left(>33^{\circ} \mathrm{N}\right.$ and $\left.<33^{\circ} \mathrm{N}\right)$, duration of sun exposure was a predictor only in children living in regions with latitude $<33^{\circ} \mathrm{N}(\beta=7 \cdot 9 ; 95 \%$ CI $0.5,15 \cdot 3 ; P=0 \cdot 04)$.

Logistic regression analysis revealed that in winter, the risk of having serum $25(\mathrm{OH}) \mathrm{D}<50 \mathrm{nmol} / 1$ increased about twofold by being a girl $(\mathrm{OR}=2 \cdot 2 ; 95 \%$ CI 1.05, 4.63; $P=0.04)$ and decreased by about $50 \%$ with exposure to the sun at 10.00-15.00 hours $v$. other times of the day (OR $=0.5 ; 95 \%$ CI 0.22, 0.99; $P=0.04)$. In summer, gender (girls $v$. boys: $\mathrm{OR}=3 \cdot 2 ; 95 \% \mathrm{CI} 2 \cdot 1,5 \cdot 0 ; P<0 \cdot 001$ ), duration of direct sun exposure $(>1 \mathrm{~h} / \mathrm{d} v .<1 \mathrm{~h} / \mathrm{d}$ : $\mathrm{OR}=0 \cdot 6$; 95\% CI 0.4, 0.94; $P=0.03$ ) and BMI status (overweight/ obese $v$. normal weight; $\mathrm{OR}=1 \cdot 8 ; 95 \%$ CI $1 \cdot 2,2 \cdot 6$; $P=0.002)$ were the important predictors of having undesirable vitamin D status (serum $25(\mathrm{OH}) \mathrm{D}<50 \mathrm{nmol} / \mathrm{l}$ ).

Multiple stepwise linear regression analysis was performed with change in serum $25(\mathrm{OH}) \mathrm{D}$ as the dependent variable and gender, age, latitude and winter concentration of serum $25(\mathrm{OH}) \mathrm{D}$ as independent variables. The final model predicting $25(\mathrm{OH}) \mathrm{D}$ included winter serum $25(\mathrm{OH}) \mathrm{D}$ concentration $(\beta=-0 \cdot 3 ; 95 \% \mathrm{CI}-0 \cdot 4,-0 \cdot 2$; $P<0 \cdot 001$ ), gender (boys $v$. girls: $\beta=9 \cdot 7 ; 95 \%$ CI 5.2, $14 \cdot 1$; $P<0.001)$ and latitude $\left(>33^{\circ} \mathrm{N} v .<33^{\circ} \mathrm{N}: \beta=4.5 ; 95 \% \mathrm{CI}\right.$ $0.09,9 \cdot 0 ; P=0.045)$ as statistically significant parameters.

Basal serum 25(OH)D was inversely correlated with the seasonal change in serum 25(OH)D $(r=-0 \cdot 16 ; P<0 \cdot 001)$. Summer rise in serum $25(\mathrm{OH}) \mathrm{D}$ among the children with vitamin D sufficiency $(25(\mathrm{OH}) \mathrm{D}>50 \mathrm{nmol} / \mathrm{l})$ was negligible, whereas among those with undesirable vitamin D status $(25(\mathrm{OH}) \mathrm{D}<50 \mathrm{nmol} / \mathrm{l})$ the summer rise was significant $(0 \cdot 5$ (sD 33.0) v. 16.1 (sD 22.0) nmol/1; $P=0 \cdot 01)$.

\section{Discussion}

To our knowledge, the present study is the first to report seasonality of vitamin D status of children in six locations in Iran covering a latitudinal gradient. Our results showed a very high prevalence of hypovitaminosis D in Iranian children of both genders residing in latitudes of $29-37^{\circ} \mathrm{N}$ of Iran, all year round.

Several studies have demonstrated low serum 25(OH)D concentrations in children across the world. Ninety-two per cent of healthy 9-12-year-old schoolchildren in $\operatorname{Iran}^{(12)}, 76 \%$ of $12-59$-month-old Jordanian children ${ }^{(33)}$, $19.5 \%$ of $6-8$-year-old Finnish children ${ }^{(34)}$ and $40 \%$ of 3-17-year-old Turkish children ${ }^{(35)}$ were reported to have circulating 25(OH)D concentration lower than $50 \mathrm{nmol} / \mathrm{l}$. Although vitamin D deficiency during childhood does not necessarily extend through adolescence and adulthood, it may exert deleterious effects on the affected child. 
We found no significant association of $25(\mathrm{OH}) \mathrm{D}$ status with age, while male gender was a predictor of higher $25(\mathrm{OH}) \mathrm{D}$ concentration in both seasons. Higher vitamin D status in boys, compared with girls, has been reported previously $^{(12)}$. Data from the US National Health and Nutrition Examination Survey (NHANES) 2003-2004 showed that, with the exception of children aged 1-5 years, females had greater risk of suboptimal $25(\mathrm{OH}) \mathrm{D}$ concentration than males ${ }^{(36)}$. Gender-specific clothing differences in outdoor activities as well as percentage of body fat ${ }^{(12,37,38)}$ can be suggested as explanations for the gender difference in vitamin D status of children.

Our data showed that direct sun exposure for more than $1 \mathrm{~h}$ in a typical summer day is a predictor of sufficient vitamin D status. However, despite higher concentration of circulating $25(\mathrm{OH}) \mathrm{D}$ during summer, prevalence of undesirable vitamin D status was still remarkable (62.6\%). Surprisingly, suboptimal vitamin D status was common even among children residing in sunny regions like Khoozestan (province 5: latitude $31 \cdot 3^{\circ} \mathrm{N}$, longitude $48 \cdot 6^{\circ} \mathrm{E}$ ) and Fars (province 6: latitude $29.6^{\circ} \mathrm{N}$, longitude $52.5^{\circ} \mathrm{E}$ ), possibly due to avoidance of direct sun exposure. Considering the potential hazards of UV radiation, the most fundamental message has been avoidance of needless sunlight exposure and usage of physical means of sun protection, particularly during midday hours ${ }^{(39)}$. This suggests that not only environmental conditions, but also individual sun behaviours and type of clothing could determine the vitamin D status of children ${ }^{(40-42)}$. Besides, for individuals residing at latitudes far from the equator, the summer accumulation of vitamin D stores could not be adequate to maintain optimal levels of circulating $25(\mathrm{OH}) \mathrm{D}^{(7)}$. Using data from three cohort studies, the main predictors of serum $25(\mathrm{OH}) \mathrm{D}$ were reported as race, UVB flux, BMI, physical activity and season of blood sampling. In general, the predictive models developed in that study could explain $25-33 \%$ of the variation in circulating $25(\mathrm{OH}) \mathrm{D}$ concentrations ${ }^{(43)}$. In contrast, the current study revealed that the effect of sun exposure on vitamin D status of children could be significant only at latitudes lower than $33^{\circ} \mathrm{N}$.

The reports of an association between latitude and vitamin D status have not been consistent. It is expected that living in a low-latitude region is accompanied by higher serum 25(OH)D concentration due to more suitable conditions for dermal vitamin D biosynthesis ${ }^{(13)}$. Some studies, including ones from Argentina ${ }^{(44)}$, Australia ${ }^{(40)}$ and China ${ }^{(45)}$, endorsed this notion. However, a metaanalysis of 394 studies demonstrated a significant decline in $25(\mathrm{OH}) \mathrm{D}$ concentration with increasing latitude just in healthy, white subjects and not in other race/ethnicities $^{(46)}$. Population-based studies should, therefore, assess individual-specific sun exposure when possible instead of relying on region of residence ${ }^{(47)}$.

High occurrence of at least one of the predefined cardiometabolic risk factors among the studied children is noteworthy. The importance of this finding lies in the fact that CVD in adulthood originates in the early years of childhood $^{(48)}$.

We found a significant association between change in circulating $25(\mathrm{OH}) \mathrm{D}$ and change in BMI among the studied children. An inverse association of serum 25(OH)D concentration with BMI in children is well established $^{(12,49,50)}$. Although little is known about the association between low 25(OH)D concentration and adiposity, it has been suggested that entrapment of vitamin D in fat cells reduces its bioavailability ${ }^{(51)}$.

One of the interesting findings of the current study was that physiological elevation of serum $25(\mathrm{OH}) \mathrm{D}$ concentration during summer was accompanied by a decrement in serum TAG, LDL cholesterol, total cholesterol and BMI in the children. Along the same line of evidence, a study on 8-11-year-old Danish children showed an inverse association between vitamin D status and certain cardiometabolic markers, including blood pressure, serum lipid profile and metabolic syndrome score, independent of body fat and physical activity ${ }^{(52)}$. The association between serum $25(\mathrm{OH}) \mathrm{D}$ and lipid profile has been reported in some previous studies ${ }^{(53,54)}$, but the results are not consistent. Only a few studies have examined the relationship between vitamin D and lipid profile in children ${ }^{(55,56)}$.

The seasonality of vitamin D status and its effects on cardiometabolic risk factors imply that keeping the vitamin D status of children adequate throughout the year, through a nationally regulated vitamin $\mathrm{D}$ fortification programme, could serve as a cost-effective measure against development of non-communicable diseases later in life. The strong case for vitamin $\mathrm{D}$ fortification is supported by studies demonstrating the efficacy of daily consumption of fortified bread, milk and orange juice in healthy adults and children $^{(57,58)}$. The other important health aspects of vitamin D seasonality relate to higher oxidative stress and immune alterations due to lower vitamin D status and resulting increased susceptibility to infections ${ }^{(59)}$. Some studies have reported an association between poor vitamin D status and urinary tract and respiratory as well as skin or soft tissue infections in children ${ }^{(60-64)}$.

The strengths of the present study include the large sample size and coverage of a rather broad latitudinal range, with fairly good distribution across the country. Serum $25(\mathrm{OH}) \mathrm{D}$ assay results were checked using the HPLC method as an attempt to harmonize the results ${ }^{(65)}$. However, some limitations must be acknowledged. First, we used no direct measures of the time spent in the sun or the actual intake of vitamin D from foods. It is noteworthy that despite decades of assessing sunlight exposure, no validated sunlight questionnaires exist ${ }^{(66)}$. Moreover, no dietary intake assessment to determine the contribution of food sources of vitamin D to circulating $25(\mathrm{OH}) \mathrm{D}$ was performed. However, our previous studies demonstrated that the contribution of dietary intake of vitamin $\mathrm{D}$ to serum $25(\mathrm{OH}) \mathrm{D}$ is probably negligible 
because the typical Iranian diet is poor in naturally occurring vitamin $\mathrm{D}^{(11,67)}$.

\section{Conclusion}

In conclusion, seasonality of vitamin D status is accompanied by corresponding changes in certain cardiometabolic risk factors in children. Therefore, it is likely that measurements from June to September may camouflage vitamin D as well as blood lipid problems at other times of the year. These findings support the urgent need for the national vitamin $\mathrm{D}$ fortification programme proposed by the Ministry of Health in Iran. Improvement of vitamin D status of the population through such community-based interventions as fortification could potentially bring about many health benefits beyond bone health. Several studies have documented the reduction of burden of disease and all-cause mortality via increasing serum concentrations of calcidiol $^{(68-70)}$. Enhanced responsiveness of children to vaccination due to raised circulating $25(\mathrm{OH}) \mathrm{D}$ is another issue that must be addressed in future studies ${ }^{(71)}$.

\section{Acknowledgements}

Acknowledgements: All of the laboratory benchwork was conducted at the Laboratory of Nutrition Research, NNFTTRI. The authors wish to thank the children and their parents for taking part in this project. They also appreciate the provincial contributors, their teams and the provincial deputies of health for their assistance, especially: Somayeh Asghari, Fariba Babai, Fariboz Bojdi, Mostafa Hosseini, Razieh Shenavar, Mahnoosh Sahebdel, Maasoomeh Moradi and Sekine Noori. Financial support: This research received no specific grant from any funding agency in the public, commercial or not-for-profit sectors. Conflict of interest: None of the authors declared a conflict of interest. Authorship: T.R.N., B.N. and Z.A. designed and supervised the study. T.R.N. and B.N. were involved in all stages of the research, including all laboratory benchwork. H.A.-M. supervised the estimation of the sample size and the statistical analyses. M.H., A.H.Y. and F.S. were involved in fieldwork arrangements and data acquisition. Ethics of buman subject participation: This study was conducted according to the guidelines laid down in the Declaration of Helsinki and all procedures involving human subjects were approved by the Ethical Committee of the NNFTRI. Verbal consent was witnessed and formally recorded.

\section{References}

1. Harris SS \& Dawson-Hughes B (1998) Seasonal changes in plasma 25-hydroxyvitamin D concentrations of young American black and white women. Am J Clin Nutr 67, 1232-1236.

2. Macdonald HM, Mavroeidi A, Barr RJ et al. (2008) Vitamin D status in postmenopausal women living at higher latitudes in the UK in relation to bone health, overweight, sunlight exposure and dietary vitamin D. Bone 42, 996-1003.

3. Seckmeyer G, Schrempf M, Wieczorek A et al. (2013) A novel method to calculate solar UV exposure relevant to vitamin D production in humans. Photochem Photobiol 89, 974-983.

4. Sayre RM \& Dowdy JC (2007) Darkness at noon: sunscreens and vitamin $\mathrm{D}_{3}$. Photochem Photobiol 83, 459-463.

5. Holick MF (2003) Vitamin D: a millennium perspective. J Cell Biochem 88, 296-307.

6. Webb AR, Kline L \& Holick MF (1988) Influence of season and latitude on the cutaneous synthesis of vitamin $\mathrm{D}_{3}$ : exposure to winter sunlight in Boston and Edmonton will not promote vitamin $\mathrm{D}_{3}$ synthesis in human skin. $J$ Clin Endocrinol Metab 67, 373-378.

7. Kull M, Kallikorm R, Tamm A et al. (2009) Seasonal variance of 25-(OH) vitamin D in the general population of Estonia, a Northern European country. BMC Public Health 9, 1.

8. Holick MF (2008) Vitamin D: a D-lightful health perspective. Nutr Rev 66, 10 Suppl. 2, S182-S194.

9. Grant WB (2006) Epidemiology of disease risks in relation to vitamin D insufficiency. Prog Biophys Mol Biol 92, 65-79.

10. Holick MF (2004) Vitamin D: importance in the prevention of cancers, type 1 diabetes, heart disease, and osteoporosis. Am J Clin Nutr 79, 362-371.

11. Nikooyeh B, Neyestani TR, Farvid M et al. (2011) Daily consumption of vitamin D - or vitamin D + calciumfortified yogurt drink improved glycemic control in patients with type 2 diabetes: a randomized clinical trial. Am J Clin Nutr 93, 764-771.

12. Neyestani TR, Hajifaraji M, Omidvar $\mathrm{N}$ et al. (2012) High prevalence of vitamin D deficiency in school-age children in Tehran, 2008: a red alert. Public Health Nutr 15, 324-330.

13. Mithal A, Wahl DA, Bonjour JP et al. (2009) Global vitamin $\mathrm{D}$ status and determinants of hypovitaminosis D. Osteoporos Int 20, 1807-1820.

14. Park S \& Johnson MA (2005) Living in low-latitude regions in the United States does not prevent poor vitamin D status. Nutr Rev 63, 203-209.

15. Wang TJ, Pencina MJ, Booth SL et al. (2008) Vitamin D deficiency and risk of cardiovascular disease. Circulation 117, 503-511.

16. Parker J, Hashmi O, Dutton D et al. (2010) Levels of vitamin $\mathrm{D}$ and cardiometabolic disorders: systematic review and meta-analysis. Maturitas 65, 225-236.

17. Lee JH, O'Keefe JH, Bell D et al. (2008) Vitamin D deficiency: an important, common, and easily treatable cardiovascular risk factor? J Am Coll Cardiol 52, 1949-1956.

18. Zittermann A, Schleithoff SS \& Koerfer R (2005) Putting cardiovascular disease and vitamin $\mathrm{D}$ insufficiency into perspective. Br J Nutr 94 , 483-492.

19. Nkooyeh B \& Neyestani T (2016) Cholesterol and vitamin D: how the 'mother' and 'daughter' molecules interact. In Handbook of Cholesterol, pp. 256-265 [RR Watson and F De Meester, editors]. Wageningen: Wageningen Academic Publishers.

20. Looker AC (2007) Do body fat and exercise modulate vitamin D status? Nutr Rev 65, 8 Pt 2, S124-S126.

21. Wang H, Xia N, Yang Y et al. (2012) Influence of vitamin D supplementation on plasma lipid profiles: a meta-analysis of randomized controlled trials. Lipids Health Dis 11, 1.

22. Hashemipour S, Larijani B, Adibi H et al. (2004) Vitamin D deficiency and causative factors in the population of Tehran. BMC Public Health 4, 38.

23. Kaykhaei MA, Hashemi M, Narouie B et al. (2011) High prevalence of vitamin D deficiency in Zahedan, southeast Iran. Ann Nutr Metab 58, 37-41.

24. Maghbooli Z, Hossein-Nezhad A, Shafaei AR et al. (2007) Vitamin D status in mothers and their newborns in Iran. BMC Pregnancy Childbirth 7, 1. 
25. Moussavi M, Heidarpour R, Aminorroaya A et al. (2005) Prevalence of vitamin D deficiency in Isfahani high school students in 2004. Horm Res 64, 144-148.

26. Rabbani A, Alavian SM, Motlagh ME et al. (2009) Vitamin D insufficiency among children and adolescents living in Tehran, Iran. J Trop Pediatr 55, 189-191.

27. Allen L, de Benoist B, Dary O et al. (editors) (2006) Guidelines on Food Fortification with Micronutrients. Geneva/Rome: WHO/FAO.

28. Chen TC, Chimeh F, Lu Z et al. (2007) Factors that influence the cutaneous synthesis and dietary sources of vitamin D. Arch Biochem Biophys 460, 213-217.

29. Calvo MS \& Lamberg-Allardt CJ (2017) Vitamin D research and public health nutrition: a current perspective. Public Health Nutr 20, 1713-1717.

30. Neyestani TR, Gharavi A \& Kalayi A (2007) Determination of serum 25-hydroxy cholecalciferol using high-performance liquid chromatography: a reliable tool for assessment of vitamin D status. Int J Vitam Nutr Res 77, 341-346.

31. Sempos CT, Betz JM, Camara JE et al. (2017) General steps to standardize the laboratory measurement of serum total 25-hydroxyvitamin D. J AOAC Int 100, 1230-1233.

32. Vieth R, Chan P-CR \& MacFarlane GD (2001) Efficacy and safety of vitamin $\mathrm{D}_{3}$ intake exceeding the lowest observed adverse effect level. Am J Clin Nutr 73, 288-294.

33. Nichols EK, Khatib IM, Aburto NJ et al. (2015) Vitamin D status and associated factors of deficiency among Jordanian children of preschool age. Eur J Clin Nutr 69, 90-95.

34. Soininen S, Eloranta AM, Lindi V et al. (2016) Determinants of serum 25-hydroxyvitamin D concentration in Finnish children: the Physical Activity and Nutrition in Children (PANIC) study. Br J Nutr 115, 1080-1091.

35. Erol M, Yigit O, Kucuk SH et al. (2015) Vitamin D deficiency in children and adolescents in Bagcilar, Istanbul. J Clin Res Pediatr Endocrinol 7, 134-139.

36. Yetley EA (2008) Assessing the vitamin D status of the US population. Am J Clin Nutr 88, issue 2, 558S-564S.

37. Moore C \& Liu Y (2015) Adiposity predicts vitamin D status of children. FASEB J 26, 1 Suppl., 747.19.

38. Moore CE \& Liu Y (2016) Low serum 25-hydroxyvitamin D concentrations are associated with total adiposity of children in the United States: National Health and Examination Survey 2005 to 2006. Nutr Res 36, 72-79.

39. International Commission on Non-Ionizing Radiation Protection (2004) Guidelines on limits of exposure to ultraviolet radiation of wavelengths between $180 \mathrm{~nm}$ and $400 \mathrm{~nm}$ (incoherent optical radiation). Health Phys 87, 171-186.

40. van der Mei IA, Ponsonby AL, Engelsen O et al. (2007) The high prevalence of vitamin D insufficiency across Australian populations is only partly explained by season and latitude. Environ Health Perspect 115, 1132-1139.

41. Holick MF (1995) Environmental factors that influence the cutaneous production of vitamin D. Am J Clin Nutr 61, 3 Suppl., 638S-645S.

42. Holick MF (2008) Deficiency of sunlight and vitamin D. BMJ 336, 1318-1319

43. Bertrand KA, Giovannucci E, Liu Y et al. (2012) Determinants of plasma 25-hydroxyvitamin $\mathrm{D}$ and development of prediction models in three US cohorts. Br J Nutr $\mathbf{1 0 8}$, 1889-1896.

44. Oliveri B, Plantalech L, Bagur A et al. (2004) High prevalence of vitamin $D$ insufficiency in healthy elderly people living at home in Argentina. Eur J Clin Nutr 58, 337-342.

45. Wat W, Leung J, Tam S et al. (2007) Prevalence and impact of vitamin D insufficiency in southern Chinese adults. Ann Nutr Metab 51, 59-64.

46. Hagenau T, Vest R, Gissel TN et al. (2009) Global vitamin D levels in relation to age, gender, skin pigmentation and latitude: an ecologic meta-regression analysis. Osteoporos Int 20, 133-140.
47. Millen AE \& Bodnar LM (2008) Vitamin D assessment in population-based studies: a review of the issues. Am J Clin Nutr 87, issue 4, 1102S-1105S.

48. Kavey RE, Daniels SR, Lauer RM et al. (2003) American Heart Association guidelines for primary prevention of atherosclerotic cardiovascular disease beginning in childhood. Circulation 107, 1562-1566.

49. Gagnon C, Baillargeon JP, Desmarais G et al. (2010) Prevalence and predictors of vitamin D insufficiency in women of reproductive age living in northern latitude. Eur J Endocrinol 163, 819-824.

50. Prakash S, Mehta NC, Dabhi AS et al. (2010) The prevalence of headache may be related with the latitude: a possible role of vitamin D insufficiency? J Headache Pain 11, 301-307.

51. Wortsman J, Matsuoka LY, Chen TC et al. (2000) Decreased bioavailability of vitamin D in obesity. Am J Clin Nutr $\mathbf{7 2}$, 690-693.

52. Petersen RA, Dalskov S-M, Sørensen LB et al. (2015) Vitamin D status is associated with cardiometabolic markers in 8-11year-old children, independently of body fat and physical activity. Br J Nutr 114, 1647-1655.

53. Jorde R \& Grimnes G (2011) Vitamin D and metabolic health with special reference to the effect of vitamin $D$ on serum lipids. Prog Lipid Res 50, 303-312.

54. Jorde R, Figenschau Y, Hutchinson M et al. (2010) High serum 25-hydroxyvitamin D concentrations are associated with a favorable serum lipid profile. Eur J Clin Nutr 64, 1457-1464

55. Nikooyeh B, Abdollahi Z, Hajifaraji M et al. (2017) Vitamin D status, latitude and their associations with some health parameters in children: national food and nutrition surveillance. J Trop Pediatr 63, 57-64.

56. Liu X, Xian Y, Min M et al. (2016) Association of 25-hydroxyvitamin D status with obesity as well as blood glucose and lipid concentrations in children and adolescents in China. Clin Chim Acta 455, 64-67.

57. Nikooyeh B, Neyestani TR, Zahedirad M et al. (2016) Vitamin D-fortified bread is as effective as supplement in improving vitamin D status: a randomized clinical trial. J Clin Endocrinol Metab 101, 2511-2519.

58. Neyestani TR, Hajifaraji M, Omidvar $N$ et al. (2014) Calcium-vitamin D-fortified milk is as effective on circulating bone biomarkers as fortified juice and supplement but has less acceptance: a randomised controlled schoolbased trial. J Hum Nutr Diet 27, 606-616.

59. Nikooyeh B \& Neyestani TR (2016) Oxidative stress, type 2 diabetes and vitamin D: past, present and future. Diabetes Metab Res Rev 32, 260-267.

60. McNally JD, Leis K, Matheson LA et al. (2009) Vitamin D deficiency in young children with severe acute lower respiratory infection. Pediatr Pulmonol 44, 981-988.

61. Esposito S, Baggi E, Bianchini S et al. (2013) Role of vitamin $\mathrm{D}$ in children with respiratory tract infection. Int J Immunopathol Pharmacol 26, 1-13.

62. Tekin M, Konca C, Celik V et al. (2015) The association between vitamin $\mathrm{D}$ levels and urinary tract infection in children. Horm Res Paediatr 83, 198-203.

63. Wang JW, Hogan PG, Hunstad DA et al. (2015) Vitamin D sufficiency and Staphylococcus aureus infection in children. Pediatr Infect Dis J 34, 544-545.

64. Ovunc Hacihamdioglu D, Altun D, Hacihamdioglu B et al. (2016) The association between serum 25-hydroxy vitamin D level and urine cathelicidin in children with a urinary tract infection. J Clin Res Pediatr Endocrinol 8, 325-329.

65. Nikooyeh B, Samiee SM, Farzami MR et al. (2017) Harmonization of serum 25-hydroxycalciferol assay results from high-performance liquid chromatography, enzyme immunoassay, radioimmunoassay, and immunochemiluminescence systems: a multicenter study. J Clin Lab Anal 31, e22117. 
66. McCarty CA (2008) Sunlight exposure assessment: can we accurately assess vitamin D exposure from sunlight questionnaires? Am J Clin Nutr 87, issue 4, 1097S-1101S.

67. Neyestani TR, Gharavi A \& Kalayi A (2008) Iranian diabetics may not be vitamin $\mathrm{D}$ deficient more than healthy subjects. Acta Med Iran 46, 337-341.

68. Grant WB, Schwalfenberg GK, Genuis SJ et al. (2010) An estimate of the economic burden and premature deaths due to vitamin D deficiency in Canada. Mol Nutr Food Res $\mathbf{5 4}$ $1172-1181$.
69. Wei MY \& Giovannucci EL (2010) Vitamin D and multiple health outcomes in the Harvard cohorts. Mol Nutr Food Res 54, 1114-1126.

70. Grant WB (2011) An estimate of the global reduction in mortality rates through doubling vitamin D levels. Eur J Clin Nutr 65, 1016-1026.

71. Sadarangani SP, Whitaker JA \& Poland GA (2015) 'Let there be light': the role of vitamin $\mathrm{D}$ in the immune response to vaccines. Expert Rev Vaccines 14, $1427-1440$. 